\title{
Original article \\ Comparative study on differences in lung parameter between the obese and non obese collegiate sedentary students \\ Yen JKS $S^{1}$, Mahadevi $B^{2}$, Arun. $B^{3}$
}

\begin{abstract}
$\underline{\text { Abstract }}$
Background: Obesity is a chronic and complex disorder which is characterized by an excessive accumulation of body fat that affects the normal healthy body. Obesity will influences functions of various systems in the body. Fat accumulation may influence lung function which might deteriorate respiratory well-being. Studies have identified those obese individuals prone to have respiratory symptoms like dyspnea when compared with non obese individuals. Method: So this study aims to find out the lung parameter differences between the obese and non obese collegiate students. Cross sectional study design which involves 80 collegiate students was selected for this study using non probability sampling method. Based on the BMI the students were classified as Obese and Non obese. Result: 40 students with obesity (Class I) and 40 students were non obese all students were ranged with the age group of $18-32$ yrs. Once the consent was obtained from the participants all are asked to do the tasks which include six minute walk test and spirometry. Conclusion: The walking time and the FVC, FEV1/FVC \& PEFR values were identified. Inferential statistics were done between the groups and the study shows that there was significant differences exist in the walking time and the FVC, FEV1/FVC values between Obese and Non obese individuals.

Keywords: Obese; Non Obese; FVC FEV1/ FVC; PEFR; Six minute walk test.
\end{abstract}

Bangladesh Journal of Medical Science Vol. 17 No. 03 July'18. Page : 351-354 DOI: http://dx.doi.org/10.3329/bjms.v17i3.36988

\section{Introduction}

Obesity is the major health concern in today society. India ranks third in obese next to USA and China. Developing countries like India have facing double burden where in at one end of the spectrum is obesity in children and adolescents while other end underweight. ${ }^{1}$ Studies show that $11 \%$ of adolescent and $20 \%$ of adults were obese. In 2015, World Health Organization estimate about $10 \%$ of worldwide population was obese. ${ }^{2}$ Obesity directly or indirectly causes many problems such as physical disorders, metabolic disorders, psychosocial stress and altered respiratory function. ${ }^{3-5}$ So it is therefore becomes important to increase awareness of the negative effects of obesity especially in school students.

Obesity has strong link with respiratory system. Several studies show there was physiological changes in lungs of obese individuals. ${ }^{6}$ There is notable alteration in respiratory function, pulmonary gas exchange, exercise tolerance, strength and endurance of respiratory muscle and altered respiratory pattern in obese individuals when compared with non obese. ${ }^{7}$ It also cause increase work of breathing by increase in consumption of oxygen and carbon dioxide. ${ }^{6,8}$ Obese individuals are more prone to have respiratory symptoms like dyspnea, especially during exercise, even if they do not have respiratory illness are mostly seen in obese individuals. ${ }^{9,10}$

Many studies have found that reduced lung expansion in obese individuals is related to a higher body mass index. (BMI $)^{11}$. Obesity seems to influence the mechanics of respiratory on and create an adverse effect on lung capacity, thereby reducing the exercise capacity. ${ }^{12,13}$ Collection of adipose tissues on the

1. Jessie Kho S'Sia Yen, Lecturer, MAHSA University, Malaysia.

2. Mahadevi Bharathi, Lecturer, MAHSA University, Malaysia.

3. Arun.B, Professor, K.G. College of Physiotherapy, KG ISL campus, Saravanmaptti. Coimbatore. 641035.barunmpt@gmail.com

Correspondence to: Dr. B. Arun, MPT, PhD. Professor, K.G. College of Physiotherapy, KG ISL campus, Saravanmaptti. Coimbatore.641035. barunmpt@gmail.com. India 
chest wall and abdominal wall ${ }^{14}$ causes heaviness in the chest wall which results in increased resistance in the lungs and diaphragm. This may result in reduction of elastic recoil of the lungs, alters the ventilatory volume and flow change. ${ }^{15}$

Since obesity tends to alter lung function, this would have a negative effect on health and quality of life and it may also lead to an increase in mortality and morbidity rates. ${ }^{16}$ It therefore becomes important to increase awareness on the impact of obesity on health and quality of life so as management of these issues is successful. Furthermore it may be more important to pursue this in the younger population. With stronger evidence of lung function differences between obese and non obese teenagers and young adults, there will be greater weight age and attention given to obesity management programs. Thus the aim of the study to identify the lung parameter differences between the obese and non obese collegiate students.

\section{Methodology}

A cross-sectional design was adopted in this study, since this study assesses different pulmonary variables in obese and non-obese populations at a single point in time. ${ }^{17}$ The study uses non probability sampling method, since the researchers choose samples based on particular characteristics ${ }^{18}$ which aid the researchers to answer the research questions. Participants for the study were selected from a population of 220 university students, those who me the inclusion criteria at the age of 18-32 years old were assessed for the body weight and height. 80 subjects were assessed to be obese, 50 were overweight, 60 normal weight and 30 were underweight. All these based on WHO classification of obesity. ${ }^{19}$

40 subjects with BMI More than $30 \mathrm{~kg} / \mathrm{m}^{2}$ (Obese group) and 40 subjects with BMIs of 18.5 to $25.9 \mathrm{~kg} /$ $\mathrm{m}^{2}$ (non obese group) were recruited. The study was conducted for duration of 8 weeks. The study includes age group of $18-32$ years, both genders were included where as smokers, people with chest infections, a history of tuberculosis, or lung infections were excluded from the study. The study was approved by the institutional ethical committee. All the ethical guidelines were followed during the selection and the assessment. Clear instructions were given to the participants and written consent was obtained.

The lung parameters measured includes Forced Expiratory Volume in $1^{\text {st }}$ second $\left(\mathrm{FEV}_{1}\right)$, Ratio of $\mathrm{FEV}_{1}$ to $\mathrm{FVC}\left(\mathrm{FEV}_{1} / \mathrm{FVC}\right)$, Peak Expiratory Flow
Rate (PEFR) and Six minute walk test (SMWT). Testing instructions were standardized, participants were instructed to wear loose comfortable clothing, and testing was done at least 2 hour after a meal or hot / cool drinks. ${ }^{16,20}$. The test was done in sitting with feet placed on the floor. Before testing, subjects were sitting quietly for 10 minutes, ${ }^{16}$ and were allowed to familiarize themselves with the device as well as practice the maneuvers. Nose clips were used. The procedure included taking a deep breath, placing mouth piece in subjects mouth and blowing air out as fast and as long as possible. Subjects were required to perform this test three times and the best reading was selected. 3 times and among the 3 times the best reading will be selected for analysis. Once the data were collected it was analyzed using student ' $t$ ' test.

\section{Result:}

Data was analyzed using the students ' $t$ ' test, Participants were from 18 years to 32 years old. The mean age of participants was $25.78 \pm 4.07,29 \%$ of participants were from age of 26-29 years, $27 \%$ of participants are from the age of 22-25 years, $25 \%$ of participants were at the age of $30-32$ years and $19 \%$ from $18-21$ years. When the lung function parameters were compared between the obese and the non obese individuals, the FEV1 value for the obese group was lesser than the non obese group. The mean value for the obese group was 86.9 and the non-obese was 104, with the $t$ value of 12.3 which is significant than the table value at $0.005 \%$ level of significance. When the FEV1/FVC values were analyzed, the mean for the obese group was 100 and the mean of non obese group 118, the $t$ value was 16.6 at $0.005 \%$ level of significance. This shows that the FEV1/FVC values are significantly lower in the obese group when compared to the non obese group. On comparing the six minute walk test (6MWT) the mean value is 402 meter \& 526 meters for the obese group and non obese group respectively. The calculated $t$ value was 19.9 which were higher than the table value at $0.005 \%$ level of significance. This shows that the obese participants have got lower functional capacity when compared to non obese group.

On comparing the peak expiratory flow rate (PEFR) the mean value is $67.1 \& 91.6$ for the obese group and non obese group respectively. The calculated $\mathrm{t}$ value was 12.5 which were higher than the table value at $0.005 \%$ level of significance. This shows a significantly lower rate in the obese group. 
Table I

\begin{tabular}{|c|c|c|c|c|c|c|}
\hline \multirow{2}{*}{ S.N } & \multicolumn{2}{|c|}{ Obese } & \multicolumn{2}{|c|}{ Non Obese } & \multirow{2}{*}{$\begin{array}{l}\text { Unpaired ' } t \text { ' } \\
\text { value }\end{array}$} & \multirow{2}{*}{$\begin{array}{l}\text { Level of } \\
\text { significance }\end{array}$} \\
\hline & Mean & S.D & Mean & S.D & & \\
\hline FEV & 86.9 & 4.09 & 104 & 7.77 & 12.3 & $\mathrm{P}<0.005 \%$ \\
\hline FEV1/FVC & 100 & 4.76 & 118 & 5.12 & 16.6 & $\mathrm{P}<0.005 \%$ \\
\hline PEFR & 67.1 & 11.8 & 91.6 & 3.73 & 12.5 & $\mathrm{P}<0.005 \%$ \\
\hline 6MWT & 402 & 34.4 & 526 & 19 & 19.9 & $\mathrm{P}<0.005 \%$ \\
\hline
\end{tabular}

\section{Discussion and conclusion}

The purpose of the study was to identify the lung parameter differences between the obese and non obese collegiate students. The results of this study show that there was a reduction in the pulmonary function between the obese group and the non obese group. The reduction of the lung volumes would cause an increase in lung and respiratory system obstruction. ${ }^{21-23}$ Alteration in the ventilator volumes and flows which causes a decrease in elasticity of the chest wall is common in obese group. ${ }^{15}$

Our study also shows that there was a marked reduction in the 6MWT and the lung function parameters which was similar to the previous researchers. A systemic review done by Luciana et al (2014) showed that there are reduced lung volumes and capacities in the people who are obese group ${ }^{24}$. The functional residual capacity (FRC) in obese subjects was found to be reduced. ${ }^{22,25}$. This is because the adipose tissues over the rib cage, abdomen and the visceral cavity load the chest wall. The normal main inspiratory movements such as the diaphragm contracting and pushing the abdominal contents forward and downwards and the external intercostal muscles contracting and pulling the rib upwards and forwards will be disrupted ${ }^{26}$. This leads to weakened pulmonary functions in the obese individuals. ${ }^{27-28}$ Drop in FRC and in expiratory reserve volumes can be detected, even with a minimum increase in weight. This study concludes that significant differences exist between obese group and non-obese group in the lung parameters, and it also confirms that obese individuals have lower values. There are some limitations in this study. A larger population would render this study more powerful. Future research should also look into variables such as the activity of the students, and stress which may also have some effects on the studied parameters.

\section{Conflict of interest : Nil}

Acknowledgement :

Our Sincere thanks to Padmashree Dr. G. Bakthavathsalam, Chairman, K.G.Hospital \& Post graduate Medical Institute, Mrs. Vaijayanthi M Das, Director of education, Prof V.Mohan Gandhi, HOD of Physiotherapy, K.G. College of Physiotherapy. Coimbatore, India. Asso Prof Chan Sook Chin, Asso Prof Mr. Lourdhu raj. I, All Staffs, Department of Physiotherapy, MAHSA University, Malaysia. 
Comparative study on differences in lung parameter between the obese and non obese collegiate sedentary students

\section{Reference:}

1. Ranjani H, Mehreen T S, Pradeepa R, Anjana RM, Garg R, Anand K, Mohan V.. Epidemiology of childhood overweight \& obesity in India: A systematic review. Indian J Med Res. 2016 Aug 5;143:160-74.

2. Zammit, C., Liddicoat, H., Moonsie, I. Makker, H. Obesity and respiratory diseases. International Journal of General Medicine. 2010. 3. p.335-343.

3. Camilo, D., Ribeiro, J., Toro, A., Baracat, E. and Barros, F. Obesity and asthma: association or coincidence? $J$ Pediatr (RioJ). 2010.86. p.6-14.

4. Boran, P., Tokuc, G., Pisgin, B., Oktem, S., Yegin, Z. Bostan, O. Impact of obesity on ventilatory function. $J$ Pediatr (Rio J). 2007.83. p.171-176.

5. Falorni, A., Galmacci, G., Bini, V., Faraoni, F., Molinari, D., Cabiati, G., Sanasi, M., Celi, F., Di Stefano, G., Berioli, M., Contessa, G. and Bacosi, M. Using obese-specific charts of height and height velocity for assessment of growth in obese children and adolescents during weight excess reduction. Eur J Clin Nutr. 1999.53. p.181-188.

6. Salome, C., King, G. and Berend, N. Physiology of obesity and effects on lung function. J Appl Physiol. 2010. 108. p.206-211.

7. Huisstede, A., Cabezas, M., Birnie, E., Van De Geijn, G.,Rudolphus, A., Mannaerts, G., Njo, T., Hiemstra, P. and Braunstahl, G. Systemic inflammation and lung function impairment in morbidly obese subjects with themetabolic syndrome. J Obes. 2013. p.8.

8. Rasslan, Z. and Saad, R. Evaluation of pulmonary function in class I and II obesity. J Bras Pneumol. 2004 30. p.508-514.

9. Bai, J., Peat, J., Berry, G., Marks, G. and Woolcock. A. Questionnaire items that predict asthma and other respiratory conditions in adults. Chest. 1998. 114. p.1342-1348.

10. Sahebjami H. Dyspnea in obese healthy men. Chest. 1998 ;114. p.1373-1377.

11. Pelosi, P., Croci, M., Ravagnan, I., Vicardi, P. and Gattinoni, L. Total respiratory system, lung, and chest wall mechanics in sedated-paralyzed postoperative morbidly obese patients. Chest. 1996. 109. p.144-151.

12. Parameswaran, K., Todd, C. and Soth, M. Altered respiratory physiology in obesity. Can Respir J. 2006.13. p.203-210.

13. Ray, C., Sue, D., Bray, G., Hansen, J. and Wasserman, K. Effects of obesity on respiratory function. Am Rev Respir Dis. 1983; 128. p.501-506.

14. Wannamethee, S., Shaper, A. and Whincup, P. Body fat distribution, body composition, and respiratory function in elderly men. Am J Clin Nutr. 2005 82. p.996-1003.

15. Pankow, W., Podszus, T. and Gutheil, T. Expiratory flow limitation and intrinsic positive end expiratory pressure in obesity. J Appl Physiol. 1998. 85. p.1236-1243.

16. Srinivas, C., Madhavi, L., Surya, K. and Surendranath, T. Comparative Study Of Dynamic Lung Function Tests In Obese and Non-Obese Individuals. Journal of Evolution of Medical and Dental Sciences. 2013 2(35). p.6736-6742.

17. Kate, A. Study design III: Cross-sectional studies. Evidence-Based Dentistry. 2006. 7. p.24-25.

18. Ma Dolores, C. Purposive Sampling as a Tool for Informant Selection. Ethnobotany Research \& Applications. 2007.5. p.147-158.

19. WHO/IOTF/IASO. The Asia-Pacific perspective: Redefining Obesity and its Treatment. Melbourne, Australia: Health Communications Australia. 2000

20. Kalpana, B., Jnaneshwara, P., Shankar, B., Bhima, B., Shiva, K. and Preethi, G. Lung Function Changes in Young Obese Women - A Harbinger For Graver Outcomes. International Journal of Applied Biology and Pharmaceutical Technology. 2011.2(4). p.104-109.

21. Sin, D., Jones, R. and Man, S. Obesity is a risk factor for dyspnea but not for airflow obstruction. Arch Intern Med. 2002. 162. p.1477-1481.

22. Jones, R. and Nzekwu, M. The effects of body mass index on lung volumes. Chest. 2006. 130. p.827-833.

23. Collins, L., Hobert, P. and Walker, J. The effect of body fat distribution on pulmonary function tests. Chest. 1995. 107. p.1298-1302.

24. Luciana, C., Maria, A. and Ana, C. Obesity and lung function: a systematic review. Obesity and lung function. 2014.12(1). p.120-125.

25. Pelosi, P., Croci, M., Ravagnan, I., Tredici, S., Pedoto, A., Lissoni, A. and Gattinoni, L. The effects of body mass on lung volumes, respiratory mechanics, and gas exchange during general anesthesia. Anesth Analg. 1998. 87. p.654-660.

26. Rabec C, De Lucas Ramos P, Veale D. respiratory complications of obesity. Arch bronconeumol. 2011 47(5). P.252-261.

27. 27. Baqui Billah SM, Jahan MS. Metabolic syndrome in urban and rural communities of Bangladesh. International Journal of Human and Health Sciences (IJHHS),2018. 2 (2) p. 71-77doi:http://dx.doi.org/10.31344/ijhhs.v2i2.29

28. Salome, C., King, G. and Berend, N. Physiology of obesity and effects on lung function. J Appl Physiol. 2010.108. p.206-211. 